\title{
Configuration Selection Based On Lifecycle Cost Of Subsea Production System: Case Of Indonesia Deepwater Field
}

\author{
Christoffel.F.B. Sa'u ${ }^{1}$, Daniel.M.Rosyid ${ }^{2}$
}

\begin{abstract}
Subsea tie back systems are important parts of oil and gas production project. The decision to select a subsea tie-back configuration with the objective goal of lowest lifecycle cost can be configured in multiple ways based on the field specifications and operator's approach to operation. This paper presents an Analytic Hierarchy Process (AHP) method to determine economical levels of subsea tie-back wells configuration, based on lifecycle cost of subsea deepwater production systems with respect to wells number alternative. Field reservoir located in deepwater of eastern Indonesian with the depth of $\mathbf{1 4 0 0}$ meters and field life $\mathbf{4 0}$ years is studied. From this study, it is identified that the most economical configuration in subsea production systems: satellite tie-back configuration to develop small field with 6 numbers of wells; for 12 numbers of wells, template subsea tie-back configuration is the best.
\end{abstract}

Keywords—Lifecycle Cost, Subsea Production System, Deepwater Field, Analytic Hierarchy Process.

\section{INTRODUCTION}

$\mathrm{W}$ hen developing a field that contains oil or gas, a subsea production system is used to continuously transport oil or gas to a floating platform or an onshore platform by drilling more than one well and installing appropriate deepwater facilities. The economic analysis for field development is essentially lifecycle cost analysis, the minimum requirements are already suggested initially for the oil and gas industry by the Norwegian Standards [1].

Optimization of total lifecycle cost of deepwater production systems must include all of the cost components that must be considered to determine the most effective cost of deepwater production systems for a particular site. The methodology of cost model development by Goldsmith to predict lifecycle cost for a field development is based on statistical and judgment of reliability data, including the risk and the reliability costs associated with the field development options. The lifecycle cost elements of subsea production system include: CAPEX, OPEX, RISKEX and RAMEX [2].

The various cost elements are defined as follows:

- CAPEX: Includes material cost and costs associated with installation of the wells and systems materials include subsea trees, pipelines, PLEMs, jumpers, umbilicals, and controls systems. Installation costs include vessel spread costs multiplied by the estimated installation time and for rental or purchase of installation tools and equipment.

Christoffel.F.B. Sa'u, Departement of Ocean Engineering, Institut Teknologi Sepuluh Nopember, Surabaya, 60111, Indonesia.E-mail: christoffel@mhs.oe.its.ac.id.

Daniel.M.Rosyid, Departement of Ocean Engineering, Institu Teknologi Sepuluh Nopember, Surabaya, 60111, Indonesia.Email:dmrosyid@gmail.com.
$\mathrm{CAPEX}=($ well system materials $)+($ installation costs)

- OPEX: Includes intervention costs associated with "planned" interventions, i.e.re-completions caused by depleted reservoir zones. OPEX for this planned re-completion is intervention rig spread cost multiplied by the estimated recompletion time for each zonal re-completion. The number and timing of planned recompletions are uniquely dependent on the sitespecific reservoir characteristics and operator's field development plan.

OPEX $=$ (intervention duration) $\mathrm{x}$ (rig spread cost)

- RISKEX: Includes risk costs associated with blowouts

RISKEX $P(B O$ during lifetime $)=P($ drilling $)+$ $P($ initial completion $)+P($ normal production $)+$ $\sum P$ (workover) $+\sum P$ (re-completion)

- RAMEX: Includes lost revenues and intervention cost associated with "unplanned" intervention, i.e. interventions caused by component failures such as sand controls system failures, tubing leaks, and production tree valve failures.

RAMEX $=$ (cost of repair vessel spread cost and the component repair/change ) $\mathrm{x}$ (lost production cost)

RAMEX calculation is performed through the following four steps:

Step (1) Identify components failures modes.

Step (2) Identify costs associated with each repair operation

Step (3) Determine the frequency of component failure Step (4) Determine the cost of each subsea component failure. 
OPEX, RISKEX and RAMEX are calculated by multiplying the yearly in field-life $(\mathrm{N})$ and $(\mathrm{r})$ is the discount rate. The lifecycle cost is expressed as ; Lifecycle cost $=$ CAPEX + OPEX + RISKEX + RAMEX

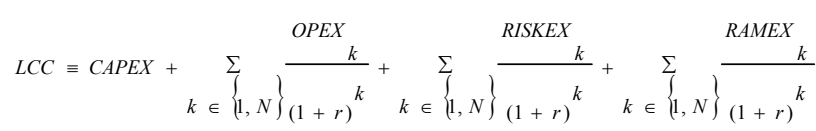

The elements of the subsea production or injection system may be configured in numerous ways, as dictated by the specific field requirements and the operator strategy [3]. Different subsea production system configuration are discussed below [4] [5] [6].

\section{Satellite Well}

A single subsea well that is tied in to a host facility with adequate infrastructure is called a satellite well. A satellite well is an individual subsea well. Often the wells are widely separated and the production is delivered by a single flowline from each well to a centrally located subsea manifold or production platform.

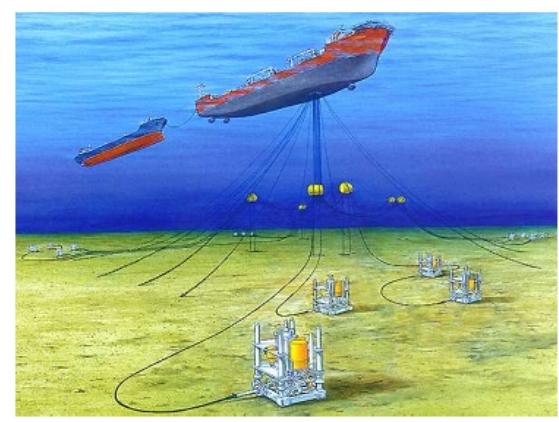

Figure 1. Satellite well (Suyanto. A, 2008)

\section{Daisy Chain}

A daisy chain configuration is a connection of various satellite wells in series, Each subsea tree may have a choke installed to avoid pressure imbalances in the flows. Daisy-chained wells allows for the combined use of infield flowlines by more than one well, and may provide a continuous loop for round-trip pigging if needed.

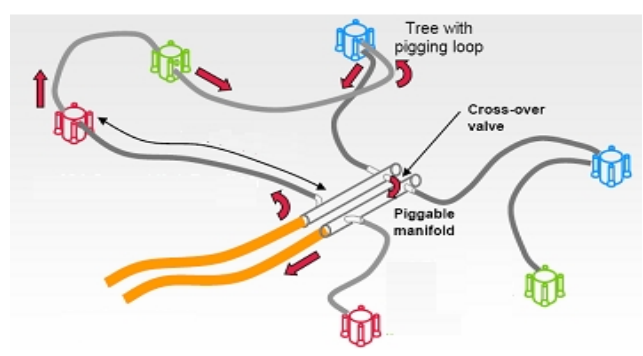

Figure 2. Well Daisy Chain (Suyanto. A, 2008)

\section{Cluster}

In a cluster arrangement, a number of single satellite wells are tied-in to a manifold. This device is used to gather and distribute fluids and is placed in proximity to the tied in wells preferably in a central location. Several wells are in proximity to one another. A separate production manifold may be placed near the wells to collect the production from all of the wells and deliver it in a single production flowline that is connected to the production facility.

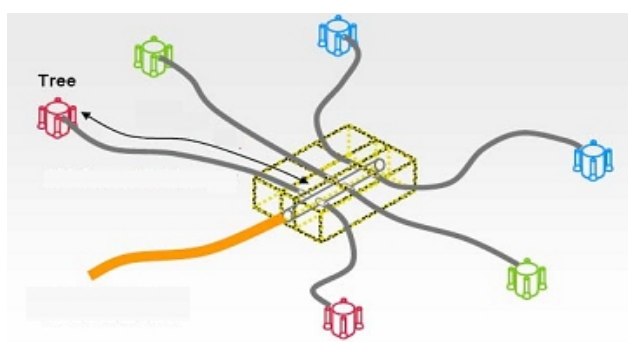

Figure 3. Well Clusters (Suyanto. A, 2008)

\section{Templates}

Well templates are structural weldments that are designed to closely position a group of well conductors. Well templates may support two wells or more than a dozen wells and manifold are situated on the same structure in a template configuration. Connections are therefore very short and are always made with rigid pipe. This allows for pre-fabrication and testing of equipment, hence reduced installation time. The template comprises of a foundation and a structural framework that provides support for seabed equipment. It may as well include protection against dropped objects and/or fishing gear.

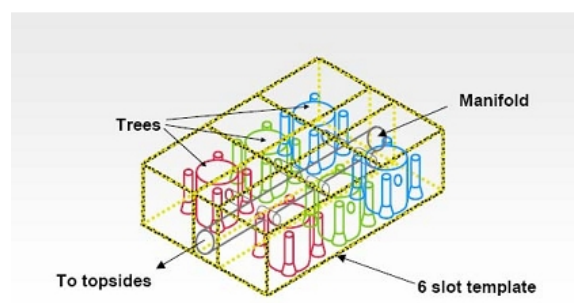

Figure 4. Well templates (Suyanto. A, 2008)

\section{METHOD}

A field of deepwater of 1400 meters. in eastern Indonesian with field life of 40 years is studied. This area is much more complicated than in other area and filled with many uncertainties since it is less explored. Thus it still has many large untested features and still has higher exploration cost and risk [7].

This study is to determine economical levels of subsea tie-back wells configuration, based on lifecycle cost of subsea deepwater production systems with respect to wells number alternative by using Analytic Hierarchy Process (AHP) Method. AHP is one of the most popular multi-criteria decision-making methods for determining the best level. This methodology developed by Saaty [8] considers a set of chosen criteria and set of alternatives among which the best solution is to be found regarding the weights of criteria and alternatives. The methodology of the AHP can be explained in the following steps. We used the steps of the method in accordance with Bhusan \& Rai [9].

Step (1) The problem is decomposed into a hierarchy of goal, criteria, sub-criteria, and alternatives. Figure 5 shows this hierarchical structure. At the root of the 
hierarchy is the goal or objective of the problem being studied and analyzed.

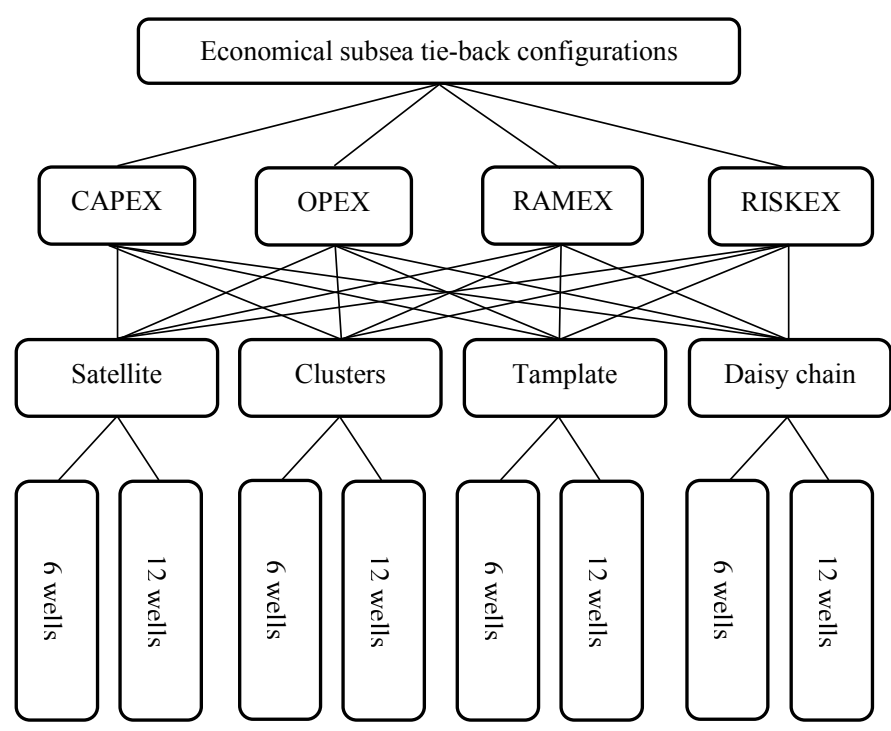

Figure 5. Hierarchical structure

Step (2) Data are collected from experts or decisionmakers corresponding to the hierarchic structure. In this study each criterion CAPEX, OPEX, RISKEX and RAMEX are calculated. The pairwise comparison of alternatives on a qualitative scale is described in Table 1. Step (3) The pairwise comparisons of various criteria generated at step 2 are organized into a square matrix.

Step (4) The principal eigenvalue and the corresponding normalized right eigenvector of the comparison matrix give the relative importance of the various criteria being compared.

Table 1. Scale of pairwise comparisons (modified. Saaty,

\begin{tabular}{|c|c|}
\hline $\begin{array}{l}\text { Intensity of } \\
\text { Value }\end{array}$ & Interpretation \\
\hline 1 & $\begin{array}{l}\text { Requirements } \mathrm{i} \text { and } \mathrm{j} \text { are of equal } \\
\text { value. }\end{array}$ \\
\hline 3 & $\begin{array}{l}\text { Requirements } \mathrm{i} \text { has a slightly lower } \\
\text { cost value then } \mathrm{j} \text {. }\end{array}$ \\
\hline 5 & $\begin{array}{l}\text { Requirements } \mathrm{i} \text { has a strongly lower } \\
\text { cost value then } \mathrm{j} \text {. }\end{array}$ \\
\hline 7 & $\begin{array}{l}\text { Requirements } \mathrm{i} \text { has a very strongly } \\
\text { lower cost value then } \mathrm{j} \text {. }\end{array}$ \\
\hline 9 & $\begin{array}{l}\text { Requirements } \mathrm{i} \text { has an absolutely } \\
\text { lower cost value then } \mathrm{j} \text {. }\end{array}$ \\
\hline $2,4,6,8$ & $\begin{array}{l}\text { These are intermediate scales between } \\
\text { two adjacent judgments. }\end{array}$ \\
\hline Reciprocals & $\begin{array}{l}\text { If requirement } i \text { has a lower value } \\
\text { then } j\end{array}$ \\
\hline
\end{tabular}

Step (5) The consistency of the matrix of order $\mathrm{n}$ is evaluated. The consistency index, CI, is calculated as

$C I \equiv \frac{(\lambda \max -n)}{(n-1)}$

where $\lambda$ max is the maximum eigenvalue of the judgment matrix.

Step 6: The rating of each alternative is multiplied by the weights of the sub-criteria and aggregated to get local ratings with respect to each criterion.

\section{RESULTS AND DISCUSSION}

Table 2 shows a matrix of pairwise comparison of the criteria in this study. The highest priority factor is given to CAPEX, with $51 \%$ relative priorities (weights) with respect to criteria RAMEX, OPEX, and RISKEX. The consistency ratio (CR) indicates an acceptable level of consistency and largest eigenvalue of matrix $\lambda \max$ 4.1687.

Table 2. Pairwise comparison matrix for the first level.

\begin{tabular}{lccccc}
\hline Criteria & CAPEX & OPEX & RAMEX & RISKEX & $\begin{array}{l}\text { Priority } \\
\text { factor }\end{array}$ \\
\hline CAPEX & 1 & 5.00 & 2.00 & 9.00 & 0.51 \\
OPEX & 0.20 & 1 & 0.25 & 5.00 & 0.13 \\
RAMEX & 0.50 & 4.00 & 1 & 7.00 & 0.32 \\
RISKEX & 0.11 & 0.20 & 0.14 & 1 & 0.04 \\
\hline & & & & \multicolumn{2}{r}{$\lambda \max =4.1687$} \\
& & & & & $\mathrm{CI}=0.0562$ \\
$\mathrm{CR}$ & $=0.0568$
\end{tabular}

Pairwise comparison of criteria, sub-criteria, and alternative (6 number of wells) with respect to each other are represented in Tables 3,4,5 and 6 respectively.

Table 3. 6 wells pairwise comparisons with CAPEX criteria.

\begin{tabular}{cccccc}
\hline $\begin{array}{c}\text { CAPEX } \\
6 \text { well }\end{array}$ & Satellite & Clusters & Template & $\begin{array}{c}\text { Daisy } \\
\text { Chain }\end{array}$ & $\begin{array}{l}\text { Priority } \\
\text { factor }\end{array}$ \\
\hline Satellite & 1 & 7.00 & 5.00 & 3.00 & 0.566 \\
Clusters & 0.14 & 1 & 0.20 & 0.33 & 0.060 \\
Template & 0.20 & 5.00 & 1 & 0.50 & 0.164 \\
$\begin{array}{c}\text { Daisy } \\
\text { Chain }\end{array}$ & 0.33 & 3.00 & 2.00 & 1 & 0.209 \\
\hline & & & & $\lambda \max =4.2115$ \\
& & & & $\begin{array}{r}\mathrm{CI}=0.0705 \\
\mathrm{CR}=0.0712\end{array}$
\end{tabular}

Table 4. 6 wells pairwise comparisons with OPEX criteria.

\begin{tabular}{|c|c|c|c|c|c|}
\hline $\begin{array}{r}\text { OPEX } \\
6 \text { well } \\
\end{array}$ & Satellite & Clusters & Template & $\begin{array}{l}\text { Daisy } \\
\text { Chain }\end{array}$ & $\begin{array}{l}\text { Priority } \\
\text { factor }\end{array}$ \\
\hline Satellite & 1 & 0.33 & 0.20 & 0.14 & 0.057 \\
\hline Clusters & 3.00 & 1 & 0.33 & 0.20 & 0.122 \\
\hline Template & 5.00 & 3.00 & 1 & 0.33 & 0.263 \\
\hline $\begin{array}{l}\text { Daisy } \\
\text { Chain }\end{array}$ & 7.00 & 5.00 & 3.00 & 1 & 0.558 \\
\hline & & & & \multicolumn{2}{|c|}{$\begin{aligned} \lambda \max & =4.1185 \\
\mathrm{CI} & =0.0395 \\
\mathrm{CR} & =0.0399\end{aligned}$} \\
\hline
\end{tabular}


Table 5. 6 wells pairwise comparisons with RAMEX

\begin{tabular}{|c|c|c|c|c|c|}
\hline $\begin{array}{c}\text { RAMEX } \\
6 \text { well }\end{array}$ & Satellite & Clusters & Template & $\begin{array}{l}\text { Daisy } \\
\text { Chain }\end{array}$ & $\begin{array}{l}\text { Priority } \\
\text { factor }\end{array}$ \\
\hline Satellite & 1 & 0.33 & 5.00 & 3.00 & 0.263 \\
\hline Clusters & 3.00 & 1 & 7.00 & 5.00 & 0.558 \\
\hline Template & 0.20 & 0.14 & 1 & 0.33 & 0.057 \\
\hline $\begin{array}{l}\text { Daisy } \\
\text { Chain }\end{array}$ & 0.33 & 0.20 & 3.00 & 1 & 0.122 \\
\hline & & & & \multicolumn{2}{|c|}{$\begin{aligned} \lambda \max & =4.1185 \\
\mathrm{CI} & =0.0395 \\
\mathrm{CR} & =0.0399\end{aligned}$} \\
\hline
\end{tabular}

Table 8. 12 wells pairwise comparisons with OPEX criteria.

\begin{tabular}{|c|c|c|c|c|c|}
\hline $\begin{array}{l}\text { OPEX } \\
12 \text { well }\end{array}$ & Satellite & Clusters & Template & $\begin{array}{l}\text { Daisy } \\
\text { Chain }\end{array}$ & $\begin{array}{l}\text { Priority } \\
\text { factor }\end{array}$ \\
\hline Satellite & 1 & 0.33 & 0.20 & 0.14 & 0.057 \\
\hline Clusters & 3.00 & 1 & 0.33 & 0.20 & 0.122 \\
\hline emplate & 5.00 & 3.00 & 1 & 0.33 & 0.263 \\
\hline $\begin{array}{l}\text { Daisy } \\
\text { Chain }\end{array}$ & 7.00 & 5.00 & 3.00 & 1 & 0.558 \\
\hline & & & & \multicolumn{2}{|c|}{$\begin{aligned} \lambda \max & =4.1185 \\
\mathrm{CI} & =0.0395 \\
\mathrm{CR} & =0.0399\end{aligned}$} \\
\hline
\end{tabular}

Table 6. 6 wells pairwise comparisons with RISKEX criteria.

\begin{tabular}{|c|c|c|c|c|c|}
\hline $\begin{array}{c}\text { RISKEX } \\
6 \text { well }\end{array}$ & Satellite & Clusters & Template & $\begin{array}{l}\text { Daisy } \\
\text { Chain }\end{array}$ & $\begin{array}{l}\text { Priority } \\
\text { factor }\end{array}$ \\
\hline Satellite & 1 & 0.50 & 5.00 & 3.00 & 0.308 \\
\hline Clusters & 2.00 & 1 & 7.00 & 3.00 & 0.469 \\
\hline Template & 0.20 & 0.14 & 1 & 0.20 & 0.053 \\
\hline $\begin{array}{l}\text { Daisy } \\
\text { Chain }\end{array}$ & 0.33 & 0.33 & 0.33 & 1 & 0.170 \\
\hline & & & & \multicolumn{2}{|c|}{$\begin{array}{r}\lambda \max =3.7907 \\
\mathrm{CI}=-0.0698 \\
\mathrm{CR}=-0.0705\end{array}$} \\
\hline
\end{tabular}

Table 9. 12 wells pairwise comparisons with RAMEX criteria.

\begin{tabular}{|c|c|c|c|c|c|}
\hline $\begin{array}{r}\text { RAMEX } \\
12 \text { well }\end{array}$ & Satellite & Clusters & Template & $\begin{array}{l}\text { Daisy } \\
\text { Chain }\end{array}$ & $\begin{array}{l}\text { Priority } \\
\text { factor }\end{array}$ \\
\hline Satellite & 1 & 0.33 & 5.00 & 3.00 & 0.263 \\
\hline Clusters & 3.00 & 1 & 7.00 & 5.00 & 0.558 \\
\hline Template & 0.20 & 0.14 & 1 & 0.33 & 0.057 \\
\hline $\begin{array}{l}\text { Daisy } \\
\text { Chain }\end{array}$ & 0.33 & 0.20 & 3.00 & 1 & 0.122 \\
\hline & & & & \multicolumn{2}{|c|}{$\begin{aligned} \lambda \max & =4.1185 \\
\mathrm{CI} & =0.0395 \\
\mathrm{CR} & =0.0399\end{aligned}$} \\
\hline
\end{tabular}

The data of cost calculated, showing priority factor under the CAPEX criteria with respect to 6 wells, assigns under the highest priority is satellite (Tables 3); under the OPEX criteria the highest priority is daisy chain (Table 4); under the RAMEX criteria the highest priority is clusters (Table 5) and under the RISKEX criteria the highest priority is also clusters (Table 6).

Tables 7, 8, 9 and 10 present the matrices of comparisons of the criteria CAPEX, OPEX, RAMEX and RISKEX with respect to the sub-criteria and their alternatives (12 number of wells).

Table 10. 12 wells pairwise comparisons with RISKEX criteria.

\begin{tabular}{|c|c|c|c|c|c|}
\hline $\begin{array}{c}\text { RISKEX } \\
12 \text { well } \\
\end{array}$ & Satellite & Clusters & Template & $\begin{array}{l}\text { Daisy } \\
\text { Chain } \\
\end{array}$ & $\begin{array}{l}\text { Priority } \\
\text { factor }\end{array}$ \\
\hline Satellite & 1 & 3.00 & 7.00 & 5.00 & 0.558 \\
\hline Clusters & 0.33 & 1 & 5.00 & 3.00 & 0.263 \\
\hline Template & 0.14 & 0.20 & 1 & 0.33 & 0.057 \\
\hline $\begin{array}{l}\text { Daisy } \\
\text { Chain }\end{array}$ & 0.20 & 0.33 & 0.33 & 1 & 0.122 \\
\hline & & & & \multicolumn{2}{|c|}{$\begin{array}{r}\lambda \max =3.8073 \\
C I=-0.0642 \\
C R=-0.0649\end{array}$} \\
\hline
\end{tabular}

The matrix of pairwise comparisons of 12 wells are obtained: under the CAPEX criteria, the highest priority is template (Table 7); under the OPEX criteria, the highest priority is daisy chain (Table 8); under the RAMEX criteria, the highest priority is clusters (Table 9), and RISKEX criteria, the highest priority is satellite (Table 10).

$$
\begin{aligned}
\mathrm{CI} & =0.0671 \\
\mathrm{CR} & =0.0678
\end{aligned}
$$

Using the AHP method. We are able to determine the ranking of subsea production operating systems configuration. The selection problem based on lifecycle cost of deepwater oil and gas field cases in Indonesia, can be summarized as shown below. 
Table 11. Economical level of subsea tie-back configurations with respect to 6 wells.

\begin{tabular}{ccc}
\hline $\begin{array}{c}\text { Subsea tie-back } \\
\text { wells } \\
\text { configuration }\end{array}$ & 6 Wells & Rank \\
\hline Satellite & 0.39 & 1 \\
Clusters & 0.24 & 2 \\
Daisy Chain & 0.22 & 3 \\
Template & 0.14 & 4 \\
\hline
\end{tabular}

These results have taught that thorough cost components must be considered. Evaluation of lifecycle operation is required to determine the most economical wells configuration systems. Satellite is the highest ranking for solution smaller fields development with limit wells shown Table 11. This configuration is a new approach for decision making of investment the subsea field development, which will help reduce both capital investment (CAPEX) and intervention cost of the reliability, availability, and maintainability (RAMEX) factor from wells production to host facility, especially in development of remote marginal fields with a limit of the reserves.

Table 12. Economical level of subsea tie-back configurations with respect to 12 wells.

\begin{tabular}{ccc}
\hline $\begin{array}{c}\text { Subsea tie-back } \\
\text { wells } \\
\text { configuration }\end{array}$ & 12 Wells & Rank \\
\hline Template & 0.33 & 1 \\
Daisy Chain & 0.25 & 2 \\
Clusters & 0.24 & 3 \\
Satellite & 0.18 & 4 \\
\hline
\end{tabular}

It is clear from Table 12, that subsea tie-back wells template configuration is the most economical. The groupings wells layout of template configuration is the most effective balancing, between the cost of materials and the installation cost (CAPEX). The well spacing is closely controlled by the template structure on one control and produce into a single flowline from wells to host facility (OPEX).

\section{CONCLUSION}

According to this study, the number of wells and the subsea tie-back wells productions systems configuration is sensitive in the optimization of lifecycle cost of deepwater field development. 6 wells using satellite configuration is the most economical solution than others; and groupings of 12 wells template is the most economical configuration.

\section{REFERENCES}

[1] O. R. Mata, "Model for economical analysis of oil and gas deepwater production concepts/Comparisons of Life Cycle Cost of Subsea Production Systems vs. Floating Structures with dry wellheads", Thesis Master in Offshore Technology/Subsea Technology, Norway.: University of Stavanger., 2010, pp. 34-39.

[2] R. Goldsmith, R. Eriksen, M. Childs, B. Saucier and F. J. Deegen, "Lifetime Cost of Subsea Production Systems, Prepared for subsea joint industry project, system description \& FMEA,.," Project Report Prepared for the Minerals Management Service MMS Project Number 331, Rev. 2.,Goldsmith Engineering, Inc; Det Norske Varitas,, Norway, 2000.

[3] API, "General overview of subsea production systems, Technical Report 17 TR13, First Edition," American Petroleum Institute., 2015

[4] C. Mudrak, Subsea production systems-A review of components, maintenance and reliability., Norway: Thesis Master Department of Production and Quality Engineering, Faculty of Engineering Science and Technology-Norges Teknisk-Naturvitenskapelige Universitet, 2016, pp. 12-15.

[5] A. Suyanto, Teknologi dan Instalasi Subsea, Buku Pintar Migas Indonesia Edisi I., 2008, pp. 12-14.

[6] Y. Bai and Q. Bai, Subsea Structural Engineering Handbook, ,United Kingdom.: Elsevier Inc., Oxford, OX5 1GB,, 2010, pp. 52-55.

[7] L. Liana, "Using Analytical Hierarchy Process to Determine Appropriate Minimum Attractive Rate of Return for Oil and Gas Project in Indonesia," PM world journal, vol. III, no. 2, pp. 4-5, 2014.

[8] T. L. Saaty, The Analytic Hierarchy Process, Planning, Priority Setting, Resource Allocation., New York: McGraw-Hill, 1980.

[9] N. Bhushan and K. Rai, Strategic Decision Making Applying The Analytical Hierarchy Process, ISBN 978-1-85233-756-8, IX 1121, Springer., 2004, pp. 11-20.

[10] T. L. Saaty, "Decision Making With The Analytical Hierarchy Process," Int. J. Services Sciences, vol. I, no. 1, pp. 85-87, 2008. 